\title{
ASSOCIATIONS BETWEEN DIET AND ACNE LESIONS
}

\author{
Magdalena Daszkiewicz
}

5D Clinic De Luxo Service Ltd, Wrocław, Poland

\begin{abstract}
Acne is one of the most common dermatological conditions affecting millions of people worldwide. It is assumed that the main etiological factors acne are considered to be the excessive production of sebum and hormones, and the colonisation of $P$. acnes bacteria. The relationship between diet and acne lesions is still the subject of debate and scientific criticism. On the one hand, studies suggest that an elimination diet is of no benefit in the treatment of acne, while other studies indicate that there is a close a close relationship between diet and the occurrence of acne lesions. Already in the 1970s, some scientists claimed that the course of acne could be modified by specific dietary components. Several studies have confirmed, among others, the role of a diet with a high glycemic index diet in acne exacerbation and suggested that a low glycemic index diet for several weeks may lead to a reduction in the number of acne lesions. The effect of milk consumption was also investigated in terms for its potential role in acne pathogenesis, including its ability to increase insulin levels. In the last decade, studies have also emerged to determine the effect of dark chocolate on the exacerbation of acne symptoms. To date, it has not been conclusively established which component of chocolate may have a potentially adverse effects on the course of acne. The article summaries the current knowledge on the relationship between diet and acne lesions, and discusses the results of recent studies on selected dietary components that may exacerbate acne.
\end{abstract}

Key words: acne vulgaris, diet, chocolate, risk factors

\section{STRESZCZENIE}

Trądzik jest jednym z najczęstszych schorzeń dermatologicznych dotykających miliony ludzi na całym świecie. Przyjmuje się, że głównymi czynnikami etiologicznym trądziku jest nadmierna produkcja łoju i hormonów oraz kolonizacja bakterii Propionibacterium acnes (P. acnes). Związek pomiędzy dietą a zmianami trądzikowymi nadal stanowi przedmiot dyskusji i krytyki naukowej. Z jednej strony wyniki badań sugerują, że dieta eliminacyjna nie przynosi korzyści w leczeniu trądziku, inne badania wskazują, na istnienie ścisłego związku między dietą a występowaniem zmian trądzikowych. Już w latach 70. naukowcy twierdzili, że przebieg trądziku może być modyfikowany przez określone składniki diety. Wyniki kilku badań potwierdziły między innymi rolę diety o wysokim indeksie glikemicznym w zaostrzeniu trądziku i sugerowały, że stosowanie przez kilka tygodni diety o niskim indeksie glikemicznym może prowadzić do zmniejszenia liczby zmian trądzikowych. Zbadano także wpływ spożycia mleka pod kątem jego potencjalnej roli w patogenezie trądziku, w tym zdolności do zwiększania poziomu insuliny. W ostatnim dziesięcioleciu pojawiły się również badania mające na celu określenie wpływu ciemnej czekolady na zaostrzenie objawów trądzików. Dotychczas nie ustalono jednoznacznie, który ze składników czekolady może mieć potencjalnie niekorzystny wpływ na przebieg trądziku. W artykule podsumowano dotychczasową wiedzę na temat zależności pomiędzy dietą i zmianami trądzikowymi oraz omówiono wyniki najnowszych badań dotyczących wybranych składników diety, które mogą wpływać na nasilenie trądziku.

Słowa kluczowe: trądzik pospolity, dieta, czekolada, czynniki ryzyka

\section{INTRODUCTION}

Acne is a skin disease commonly encountered throughout the world. During adolescence, most adolescents struggle with varying degrees of acne lesions. Data on the prevalence of acne in the general population range from $50-95 \%$ [12]. The main factors contributing to the pathophysiology of acne are the inflammatory response, colonisation by Propionibacterium acnes (P. acnes) and increased sebum production [22]. Dietary factors, especially sweets (including chocolate), milk and fat, are considered by many researchers as a cause or exacerbating factors of acne [11]. The aim of this study

Corresponding author: Magdalena Daszkiewicz, 5D Clinic De Luxo Service Sp z o.o.ul. Legnicka 46, 53-674 Wrocław, tel: +48 512562 496, e-mail: magdalenaiza.daszkiewicz@gmail.com

(c) Copyright by the National Institute of Public Health - National Institute of Hygiene 
is to present the relationship between diet and acne vulgaris based on a review of recent world literature.

\section{Pathophysiology of acne vulgaris}

During puberty there is an increase in adrenal androgen production, resulting in the increased sebaceous glands production of sebum, a substance consisting of sterol esters, triglycerides, cholesterol and free fatty acids that cause inflammation. The increased production of sebum and the accumulating epithelial and keratin cells block the hair follicle outlet causing swelling and the formation of a keratinous plug, which lead to the formation of an acne lesion called microcomedone (early acne). As the keratinous plug enlarges, there is an increased risk of colonisation by Propionibacterium acnes bacteria, which are the skin microbiome, causing the progression of microcomedones into comedones or vesicles. Acne lesions most commonly occur in areas of the skin where there is a high number of sebaceous glands, namely the face, neck, chest, back and upper limbs [4].

\section{Glycaemic index and glycaemic load in acne vulgaris}

The authors of many scientific studies have focused on assessing the relationship between dietary glycaemic index and insulin resistance and the risk of acne lesions or their severity. Glycaemic Index (GI) and glycemic load (GL) may be related to the development of acne because they are closely linked to the insulin response that occurs when blood glucose levels rise after a meal. The glycemic index is a method to assess the quality of carbohydrates.

Glycaemic Index is defined as the area under the blood glucose curve that develops within 2 hours of consuming a product containing $50 \mathrm{~g}$ of assimilable carbohydrate, and is expressed in relation to the area of the glycaemic curve that develops after consuming $50 \mathrm{~g}$ of pure glucose. For glucose, the GI is 100 , so the smaller the increase in glycemia, the lower the GI value. Products with a low glycemic index have a GI value of 50 or lower, with a medium GI value of 56-69 and a high GI value of 70 or higher [18].

The glycaemic load, on the other hand, takes into account both the quality of carbohydrates consumed with the product and their quantity. The glycemic load is the product of the GI of a product and the quantity of carbohydrates it contains. The result is then divided by 100. The value of products with a low GL is less than 10 , with a medium GL 10-20, and high GL includes products with a GL value higher than 20 [18].

Kaymak et al. [16] studied the relationship between acne and glycemic load and index, insulin sensitivity and plasma somatomedin C (IGF-1) levels. It was shown that serum levels of IGF-1 and significantly lower levels of insulin-like growth factor binding protein
(IGFBP-3) were higher in acne subjects compared to healthy subjects. Furthermore, as assessed by an intake questionnaire, the diet of acne subjects had a significantly higher glycaemic index than the diet of subjects without acne lesions [16].

Cerman et al. [8] conducted a study involving a 50-person study group and a 36-person control group. Respondents with acne were divided into three subgroups: with "mild" lesions (a few to several blackheads, papules and pustules; no nodules); with "moderate" lesions (several blackheads, papules and pustules; from several to more than ten nodules); with "severe" lesions (numerous blackheads, papules and pustules; many nodules). Patients who had previously received topical or systemic acne treatment were excluded from the study. The reference product was milk. Participants provided the researchers with notes every seven days listing the products and foods present in their 24-hour diets. The researchers then calculated the energy value of the diet, its glycaemic load and the proportion of energy from protein, carbohydrate and fat in the 24-hour diet using a nutrition software program (Foodworks Xyris Software). Venous blood samples were collected for examination at different times and analysed for glycaemic factors. Glycaemic index and glycaemic load values were significantly higher (respectively $\mathrm{p}=0.022$ and $\mathrm{p}=0.001$ ) and serum adiponectin levels were significantly lower ( $p$ $=0.015$ ) in patients with acne than in control group. There was also an inverse correlation between serum adiponectin levels and glycaemic index $(\mathrm{p}=0.049, \mathrm{r}$ $=-0.212$ ). The study concluded that diets with a high glycaemic load were positively associated with acne vulgaris. Adiponectin may be a pathogenic cofactor contributing to disease development [8].

In contrast, Burris et al. [6] conducted a study involving 66 participants divided into two subgroups: 34 people on a low glycaemic index and glycaemic load diet and 32 control subjects. The aim of the study was to determine changes in biochemical markers associated with moderate to severe acne after a low GI and GL diet or an usual diet plan for 2 weeks. Insulinlike growth factor IGF-1 concentrations decreased significantly among respondents following a lowGI and GL diet between pre- and post-intervention time points (pre-intervention $=267.3 \pm 85.6 \mathrm{mg}$ $/ \mathrm{ml}$, post-intervention $=244.5 \pm 78.7 \mathrm{ng} / \mathrm{ml})(\mathrm{P}=$ $0.049)$. The study showed no differences in changes in glucose, insulin, IGFBP-3 protein or insulin resistance concentrations between the study groups after 2 weeks. However, the proportion of energy derived from carbohydrates ( $\mathrm{P}<0.001)$, GI $(\mathrm{P}<0.001)$ and GL $(\mathrm{P}<0.001)$ were significantly reduced among participants following a low-GI/GL diet between preand post-intervention time points [6]. 


\section{A diet rich in dairy products and acne vulgaris}

Researchers are also investigating possible links between dairy product consumption and the pathogenesis of acne vulgaris. The probable reason for the possible comedogenic effect of milk and its products are the hormones it contains, which are produced by cows during pregnancy. However, the component of milk which stimulates the hair-sebum duct is insulin-like growth factor (IGF-1), the blood concentration of which changes depending on the severity of acne [27]. IGF-1 levels increase during puberty under the influence of growth hormone and positively correlate with the clinical course of acne. The highest IGF-1 concentrations are observed in women with acne, and the number of acne lesions positively correlates with IGF-1 plasma concentrations [23]. High plasma IGF-1 concentrations caused by milk consumption stimulate sebaceous cell proliferation, which leads to the development and progression of acne lesions [20]. A study by Ulvestad et al. [28] found that high consumption ( $\geq 2$ glasses per day) of full-fat dairy products was associated with moderate to severe acne development. In boys consuming large amounts of full-fat dairy products, the odds ratio for developing acne was 4.81 (1.59-14.56). On the other hand, high total dairy consumption was associated with the development of acne lesions in girls (1.80, 1.02-3.16). In contrast, no significant associations were found between acne and consumption of semiskimmed or skimmed dairy products or with moderate consumption of any fatty dairy products [28].

A study by Adebamowo et al. [1] investigated the alleged association between milk and dairy consumption and acne. Nearly 50,000 women participated in the study. The authors found that acne positively correlated with the reported amount of milk consumed, especially skimmed milk. The researchers hypothesised that the bioavailability of comedogenic components may increase when skimmed milk is produced. Skimmed milk contains less estrogen than full-fat milk. Estrogen is a hormone that can reduce acne lesions. Furthermore, the authors showed a positive correlation between acne and the consumption of instant products and cottage cheese. These results were explained by the cow's milk content in both products [1].

LaRosa et al. [19] investigated a possible association between the consumption of dairy products and the occurrence of acne in adolescents. Conducting a casecontrol study among 225 respondents aged 14-19 years, the authors hypothesised that adolescents with facial acne (120) would consume more dairy than those in the control group (105). Participants taking oral contraceptive pills or isotretinoin in the past 6 months were excluded from the study. The data on milk and dairy products intake were then compared with the nutritional values in both groups. The three study variables included total daily intake of dairy products, as well as total daily intake of full-fat, reduced-fat and low-fat dairy products. The variables included in the study were also data on total daily energy intake from carbohydrates, fats and protein. The mean body mass index (BMI) in the acne group was 22.8 , compared to 23.8 in the control group. The total dairy content of the diet in the acne group was found to be significantly higher $(p=0.02)$ than in the control group. In this study, there were no statistically significant differences in the total intake of full-fat ( $p$ $=0.95)$ and low-fat $(\mathrm{p}=0.36)$ dairy products between the groups. It was also found that total energy was not statistically different between the two groups ( $p$ $=0.12)$. Total fat intake $(p=0.34)$, carbohydrate $(p=$ $0.14)$ and protein $(p=0.08)$ were found to be similar in both the group of people with acne as well as in the control group [19].

\section{Chocolate and acne vulgaris}

The effect of chocolate ingredients on the exacerbation of acne lesions has been a subject of debate for several decades. Although it has been hypothesised that several factors, including body mass index, hormone levels, glucose levels, stress and glycaemic index may influence acne, the role of diet in the formation and/or worsening of acne lesions remains controversial.

To date, several hypotheses have been proposed to explain the possible influence of dairy and chocolate consumption on the exacerbation of acne symptoms. One hypothesis suggests that the sugars in dairy products and chocolate trigger insulin secretion, activating signaling pathways that ultimately lead to increased keratinocyte proliferation, which may lead to acne lesions development [26]. This may explain why some studies have found an effect of sweets and chocolate on acne symptoms [32]. Other researchers suggest that chocolate consumption increases the secretion of inflammatory cytokines by cells and thus may influence the formation of acne lesions [26].

In Western societies, acne vulgaris is a common skin disease that affects $79-95 \%$ of the adolescent population. Epidemiological data show that acne incidence rates are much lower in non-Western societies. A study by Cordain et al. [10] found that among Westerners a higher proportion of the population developed acne vulgaris than two non-Western populations, including Kitavan islanders from Papua New Guinea and Aché hunters from Paraguay. Both non-western populations followed low glycaemic load diets devoid of western refined foods such as cereals, chips, biscuits and bread. The diet of the Kitavan population consisted of vegetables, fruits, fish and coconuts. Consumption of dairy, coffee, alcohol, cereals, sugar, oils and salt was 
minimal. The diet of the Aché community included local foods $(69 \%$, including sweet cassava, peanuts, maize and rice), game (17\%), western foods $(8 \%$, containing mainly pasta, flour, sugar, yerba tea and bread), home-grown meat (3\%) and harvested forest products $(3 \%)$. Researchers have suggested that a low fat and low glycaemic load diet may account for the lack of acne in both populations [10]. The differences in acne prevalence between non-Western and fully modernised societies cannot be explained solely by different genetic factors between populations, as they are likely due to different environmental factors. Identification of these factors may help with developing a treatment regimen for acne in Western populations.

In contrast, the crossover study found no effect of chocolate on acne or on sebum production or composition. The study involved 65 people with moderate acne symptoms who were asked to consume two chocolate bars per day for a month of time. The placebo group consumed identical-looking bars that did not contain chocolate in their composition, but had a similar fat and sugar composition. Both bars weighed between $112 \mathrm{~g}$ and $114 \mathrm{~g}$, but the bar consumed by the control group contained more calories. Excessive consumption of chocolate and fat did not alter the composition or amount of sebum. Diets rich in carbohydrates or fat have not been confirmed to stimulate sebum secretion and adversely affect the development of acne vulgaris [14]. Fulton's study [14] was criticised by Rasmussen [24], who believed that an incorrect method of lesion quantification was used because all lesion types (blackheads, papules and pustules) were included to the same extent, thus making an accurate assessment of acne severity impossible.

In the 1970s, another important study was carried out with the primary aim of assessing the effects of chocolate on acne. Twenty-seven medical students participated in the study. They consumed six servings of chocolate bars (39 g each) over seven days. Facial acne lesions were counted at the beginning of the study and then daily for the seven days of the study. Although the assessment methods used were not properly described, the study did not observe a causal relationship between chocolate consumption and acne proliferation [3].

In 2011, Block et al. [5] investigated whether 100\% chocolate could directly exacerbate acne in men with a history of acne vulgaris. The study involved 10 men aged 18 to 35 years with 1 to 4 acne lesions (limited to blackheads and papules) present on the face. Participants consumed up to $340 \mathrm{~g}$ of chocolate bars on the first day of the study and followed their regular diets for a further week. The total number of blackheads, papules and pustules on the face was counted on days 4 and 7 of the study. There was a statistically significant increase in the mean number of acne outbreaks (blackheads, papules and pustules) on both day $4(\mathrm{p}=0.031)$ and day $7(\mathrm{p}=0.050)$ compared to baseline. No serious adverse events occurred in the male subjects. Rare transient adverse events included gastric complaints, nausea, vomiting and headache. The results of this study indicate that participants experienced significant changes in the severity of acne after a single ingestion of chocolate [5]. However, the authors did not provide information on the type of chocolate consumed by the subjects and the cocoa content of the samples consumed, which may have influenced the results. Dark chocolate contains more antioxidants than milk chocolate, leading to the conclusion that it may have significantly less comedogenic effects. However, this issue still remains unclear.

A study conducted by Netea et al. [21] aimed to determine the mechanisms through which chocolate may influence the development of acne. They investigated the effect of chocolate on the growth of $P$. acnes and on cytokine production stimulated by $P$. acnes or $S$. aureus. Blood samples were taken from 7 participants, before and after consumption of 50 grams of chocolate (30\% cocoa contents) for four consecutive days. Respondents had not consumed chocolate for at least one week prior to the study. No direct effect of chocolate on $P$. acnes growth was observed. On the other hand, chocolate had a stimulatory effect on pro-inflammatory cytokines, such as TNF and IL-lb, induced by $P$. acnes. Chocolate consumption increased the production of the anti-inflammatory cytokine IL10 induced by $S$. aureus, while decreasing the release of IL-22 [21].

The aim of the study carried out by Caperton et al. [7] was to evaluate the effect of chocolate on acne exacerbation in men aged 18-35 years. Women were deliberately excluded from the study to avoid the likelihood of a hormonal effect of menstruation on acne development. In addition, subjects with a history of diabetes or hypertriglyceridemia were excluded from participation in the study, as well as those who were diagnosed with obesity based on BMI. The 14 study participants were divided into three groups. The first group received capsules filled with unsweetened $100 \%$ cocoa, the second with hydrolysed gelatin powder and the third with a mixture of cocoa and hydrolysed gelatin. A statistically significant increase in the mean number of total acne lesions (blackheads, papules, pustules, nodules) was detected on both day 4 $(p=0.006)$ and day 7 of the study $(p=0.043)$, compared to baseline. No serious adverse events occurred during the study. Minor transient events included gastric discomfort, nausea and vomiting. In acne-prone men, chocolate consumption has been found to correlate with an increase in acne lesions [7]. 
The findings suggest that chocolate ingredients stimulate blood cells to release more of the proinflammatory cytokines, interleukin-1 $\beta$ and TNF $\alpha$. Delost et al. [13] conducted a study involving 54 students with acne vulgaris who were divided into two groups. The first group received for consumption a bar of Hershey's milk chocolate (43 g), while the second group received 15 Jelly Belly jellybeans, which provided the same glycemic load. The number of acne lesions was counted from photographs by a dermatologist after 48 hours. There was a statistically significant $(\mathrm{p}=0.0001)$ increase in acne lesions $(14.8$ lesions) in the chocolate eating group compared to the jelly bean eating group ( 0.7 lesions). Linear regression analysis (SPSS) was performed to assess the effect of associated variables on the number of acne lesions. None of the associated variables (age, $\mathrm{P}=0.424$; stress, $\mathrm{P}=0.901$; gender, $\mathrm{P}=0.843$ ) showed statistical significance for the number of acne lesions [13]. Since dark chocolate contains more antioxidants than milk chocolate, it shows a weaker comedogenic effect [17].

On the other hand, Vongraviopap and Asawanonda [29] conducted a study involving $25 \mathrm{men}$, aged between 18 and 30 years, with a tendency to acne. Exclusion criteria included systemic conditions that could cause acne-like lesions and local or systemic acne treatments performed in the past 4-12 weeks, including light- and laser therapy. Participants were then asked to consume $25 \mathrm{~g}$ of dark chocolate $(99 \%)$ per day for 4 weeks. Before the start of the study, a 4-week pre-study period was conducted during which the subjects did not consume cocoa-containing products. For 8 weeks (pre-study and study phase), subjects did not use any new sunscreen or moisturiser, and washed their face with a soap-free cleanser provided by the study authors. The number of acne lesions was assessed once a week. Increased numbers of blackheads and inflammatory papules were detected as early as 2 weeks after starting the study. After 4 weeks, the changes remained statistically significant compared to baseline values [29].

The effect of dark chocolate on the development of acne lesions was also confirmed by the study of Chylak et al. [9] conducted on a group of 33 men who were divided into a "young" group (20-30 years) and a middle-aged group (45-75 years). Only non-smokers and non-consumers of large amounts of alcohol (i.e., more than 35 UK units per week) participated in the study. A further inclusion criterion was the absence of visible acne symptoms. Body mass index was determined for all study participants. Values below 25 $\mathrm{kg} / \mathrm{m} 2$ were taken as body weight within the normal range, those between $25 \mathrm{~kg} / \mathrm{m} 2$ and $30 \mathrm{~kg} / \mathrm{m} 2$ as overweight and values above $30 \mathrm{~kg} / \mathrm{m} 2$ - as obesity. The subjects were then asked to consume $10 \mathrm{~g}$ of Green \& Black's dark chocolate ( $70 \%$ cocoa contents) every day immediately after lunch for four weeks. Participants were also instructed not to consume any other cocoa-containing products during the study period. Prior to the dietary intervention and at the end of the study, RSSC samples were taken from participants' faces to measure lipid droplet size, the number of exfoliated corneocytes and to assess the presence of microorganisms. The results indicate that chocolate consumption increased the number of exfoliated corneocytes in both groups of men. However, this increase was statistically significant only in young men $(p<0.001)$. The result of the t-test indicated a highly significant $(\mathrm{p}<0.001)$ increase in corneocyte exfoliation in normal weight subjects, whereas in overweight or obese subjects was non-significant. In addition, the consumption of dark chocolate resulted in a significant increase in microbial presence in both young and middle-aged men. These changes could potentially contribute to the development of acne [9].

Currently, scientists have not established whether chocolate exacerbates acne lesions, and if so, what factors determine this process. Cocoa contains a large amount of flavonoids, which should have antiinflammatory effects and beneficial effects on the functioning of many organs. However, dark chocolate also contains cocoa butter, which among other things contains 33\% monounsaturated oleic acid and 33\% stearic acid. When used in animal models, oleic acid has been shown to alter epithelial keratinisation, leading to the formation of blackheads [15].

\section{Fat intake and acne vulgaris}

High fat intake may also be a potential dietary risk factor for acne development. Despite the inconsistent results of various studies, several studies have shown that high fat intake increases the likelihood of acne. Although researchers have suggested potential mechanisms to explain the relationship, there is insufficient evidence to support this [31]. More research needs to be conducted to establish the relationship between fat intake and acne and clarify the mechanisms involved. Nevertheless, several dietary factors may have a protective effect on the development of acne lesions. The relationship between high fish intake and reduced acne risk has been debated [2]. However, Wang et al. [30] observed that seafood consumption was associated with increased acne risk, suggesting that consumption of other types of seafood may be associated with increased rather than decreased acne risk. The results of some studies suggest that a high intake of fruit and vegetables may reduce the risk of acne. The protective effect may be due to the omega- 3 fatty acids in fish and fiber in fruit and vegetables, which reduce insulin-like growth factor 1 (IGF-1) levels, thus reducing the risk of acne [25]. 


\section{CONCLUSIONS}

Further research is needed to fully elucidate the role that diet may play in both development and treatment of acne. As the typical diet in developed countries is a high-glycaemic diet often causing insulin resistance, it may therefore exacerbate sebum production and thus inflammation and acne. Contemporary research is being conducted to determine whether a diet low glycemic index diet can effectively treat or even prevent the development of acne. The question of why not every person with insulin resistance develops acne, if this is one of their risk factors, is still being sought. On the other hand, studies on the exacerbation of acne as a result of chocolate consumption remain controversial due to the additives found in it, such as fat and sugar. The role of antioxidants, omega-3 fatty acids, zinc, vitamin A, dietary fiber and iodine in acne remains unclear. It can be assumed that if a patient notices an association between a particular dietary factor and acne severity, then they should exclude it from their diet or limit their intake.

\section{Conflict of interest}

The Author declares no conflict of interest.

\section{REFERENCES}

1. Adebamawo C. A., Spiegelman D., Danby F. W., Frazier A. L., Willett W. C., Holmes M. D.: High school dietary dairy intake and teenage acne. J Am Acad Dermatol. 2005;52:207-14.

2. Al Hussein S. M., Vari C. E., Todoran N., Al Hussein H., Ciurba A., Dogaru M. T.: Diet, Smoking and Family History as Potential Risk Factors in Acne Vulgaris a Community-Based Study. Acta Medica Marisiensis 2016;62:173-81.

3. Anderson P. C.: Foods as the cause of acne. Am Fam Physician. 1971;3(3):102-103.

4. Baumann L.: Dermatologia estetyczna, Wyd. PZWL, Warszawa 2013;121-131.

5. Block S. G., Valins W. E., Caperton C. V., Viera M. H., Amini S., Berman B.: Exacerbation of facial acne vulgaris after consuming pure chocolate. J Am Acad Dermatol. 2011;65:e114-5.

6. Burris J., Shikany J. M., Rietkerk W. Woolf K.: A Low Glycemic Index and Glycemic Load Diet Decreases Insulin-like Growth Factor-1 among Adults with Moderate and Severe Acne: A Short-Duration, 2-Week Randomized Controlled Trial, J Acad. Nutr. Diet 2018;118:1874-85.

7. Caperton C., Block S., Viera M., Keri J., Berman B.: Double-blind, Placebo-controlled Study Assessing the Effect of Chocolate Consumption in Subjects with a History of Acne Vulgaris. J Clin Aesthet Dermatol. 2014;7(5):19-23.

8. Cerman A. A., Aktas E., Altunay I. K., Arici J. E., Tulunay A., Ozturk F. Y.: Dietary glycemic factors, insulin resistance, and adiponectin levels in acne vulgaris. JAAD 2016;75:155-162.

9. Chalyk N., Klochkov V., Sommereux L., Bandaletova T., Kyle N., Petyaev I.: Continuous Dark Chocolate Consumption Affects Human Facial Skin Surface by Stimulating Corneocyte Desquamation and Promoting Bacterial Colonization, J Clin Aesthet Dermatol. 2018;11:37-41.

10. Cordain L, Lindeberg S, Hurtado M, Hill K., Eaton S. B., Brand-Miller J.: Acne vulgaris: a disease of Western civilization. Arch Dermatol. 2002;138:1584-1590.

11. DawidziakJ., Balcerkiewicz M.: Dieta jako uzupełnienie leczenia trądziku pospolitego (Acne vulgaris). Część II. Kwasy tłuszczowe, indeks glikemiczny, przetwory mleczne, Farmacja Współczesna 2016;9:67-72.

12.Degitz K., Ochsendorf F.: Acne, JDDG 2017;15(7):709722.

13. Delost G. R., Delost M. E., Lloyd J.: The impact of chocolate consumption on acne vulgaris in college students: A randomized crossover study. J Am Acad Dermatol. 2016;75:220-222.

14.Fulton Jr J. E., Plewig G., Kligman A. M.: Effect of chocolate on acne vulgaris. JAMA 1969;210:2071-4.

15. Katsuta Y., Iida T., Inomata S., Denda M.: Unsaturated fatty acids induce calcium influx into keratinocytes and cause abnormal differentiation of epidermis. J Invest Dermatol 2005;124:1008-13.

16. Kaymak Y, Adisen E, Ilter N, Bideci A., Gurler D., Celik $B .:$ Dietary glycemic indexand glucose, insulin, insulinlike growth factor-I, insulin-like-growth factor binding protein 3, and leptin levels in patients with acne. J Am Acad Dermatol. 2007;57:819-23.

17. Kucharska A., Szmurto A., Sińska B.: Significance of diet in treated and untreated acne vulgaris. Postepy Dermatol Alergol 2016;33:81-86.

18. Kulczyński B., Gramza-Michałowska A.: Znaczenie indeksu i ładunku glikemicznego w zapobieganiu rozwoju chorób sercowo-naczyniowych. Probl Hig Epidemiol 2015;96:51-56.

19. LaRosa C. L., Quach K. A., Koons K., Kunselman A. R., Zhu J., Thiboutot D. M., Zaenglein A. L.: Consumption of dairy in teenagers with and without acne, JAAD 2016;75:318-322.

20.Mirdamadi Y., Thielitz A., Wiede A., Goihl A., Papakonstantinou E., Hartig R., Zouboulis C.C., Reinhold D., Simeoni L., Bommhardt U., Quist S., Gollnick H.: Insulin and insulin-like growth factor-1 can modulate the phosphoinositide-3-kinase/Akt/ FoxO1 pathway in SZ95 sebocytes in vitro. Mol. Cell. Endocrinol. 2015;415:32-44.

21. Netea S. A., Janssen S.A., Jaeger M., Jansen T., Jacobs L., Miller-Tomaszewska G., Plantinga T. S., Netea M. G., Joosten L. A. B.: Chocolate consumption modulates cytokine production in healthy individuals, Cytokine. 2013;62:40-43

22. Nowicka $D$.: Dermatologia. Ilustrowany podręcznik dla kosmetologów. Wyd. KosMeD, Wrocław 2014;56-67.

23. Rahaman S.M.A., De D., Handa S., Pal A., Sachdeva N., Ghosh T., Kamboj P.: Association of insulin-like growth 
factor (IGF)-1 gene polymorphisms with plasma levels of IGF-1 and acne severity. JAAD 2016;75:768-773.

24.Rasmussen J. E.: Diet and acne. Int J Dermatol. 1977; 16:488-492.

25. Spencer E. H., Ferdowsian H. R., Barnard N. D.: Diet and acne: a review of the evidence. Int J Dermatol. 2009;48:339-47.

26.Tan J. K., Bhate K.: A global perspective on the epidemiology of acne. Br J Dermatol. 2015;172 (Suppl 1):3-12.

27. Tuchayi S. M., Makrantonaki E., Ganceviciene R., Dessinioti C., Feldman S.R., Zouboulis C.C.: Acne vulgaris. Nat. Rev. Dis. Primers 2015;1:15029.

28. Ulvestad M., Bjertness E., Dalgard F., Halvorsen J. A.: Acne and dairy products in adolescence: results from a Norwegian longitudinal study, J Eur. Acad. Dermatol Venereol. 2017;31:530-535.
29. Vongraviopap S., Asawanonda P.: Dark chocolate exacerbates acne. Int J Dermatol. 2016;55:587-91.

30.Wang P., Wang H., Ding H., Lv T., Miao F., Li J., Shi $L$., Wang $X$ : Risk factors, psychological impacts and current treatments of acne in Shanghai area of China. J Dermatolog Treat. 2016;27:146-7.

31. Wolf, R., Matz, H., Orion, E.: Acne and diet. Clin Dermatol. 2004. 22(5):387-93.

32.Wolkenstein P., Misery L., Amici J. M., Maghia R., Branchoux S., Cazeau Ch., Voisard J. J., Taïeb Ch.: Smoking and dietary factors associated with moderateto-severe acne in French adolescents and young adults: results of a survey using a representative sample. Dermatology. 2015;230:34-9.

Received: 06.04.2021

Accepted: 28.05.2021 